\title{
Measurement of estrogenic activity in sediments from Haihe and Dagu River, China
}

\author{
Maoyong Song ${ }^{\mathrm{a}, \mathrm{b}}$, Yan Xu ${ }^{\mathrm{b}}$, Qinting Jiang ${ }^{\mathrm{b}}$, Paul K.S. Lam ${ }^{\mathrm{b}}$, Desmond K. O’Toole ${ }^{\mathrm{b}}$, \\ John P. Giesy ${ }^{b, c}$, Guibin Jiang ${ }^{a, *}$ \\ ${ }^{a}$ State Key Laboratory of Environmental Chemistry and Ecotoxicology, Research Center for Eco-Environmental Sciences, \\ Chinese Academy of Sciences, P.O. Box 2871, Beijing, 100085, China \\ ${ }^{\mathrm{b}}$ Research Centre for Coastal Pollution and Conservation, Department of Biology and Chemistry, City University of Hong Kong, \\ Tat Chee Avenue, Kowloon, Hong Kong \\ ${ }^{\mathrm{c}}$ Department of Zoology, National Food Safety and Toxicology Center, Institute of Environmental Toxicology, Michigan State University, \\ East Lansing, MI 48824, USA
}

Received 6 November 2005; accepted 1 March 2006

Available online 19 April 2006

\begin{abstract}
Sediments from two rivers in China, the Haihe and Dagu Rivers, were examined for estrogenic activity using an estrogen receptor (ER)mediated in vitro bioassay system. ER-active compounds were isolated from sediments by Soxhlet extraction, and the crude extracts were fractionated using a florisil column into three fractions. The estrogenic activity of each extract was detected by measuring luciferase activity in the human breast cancer cell line MCF-7 transfected with a luciferase receptor gene. Significant estrogenic activity was observed in each total extract. The $17 \beta$-estradiol equivalents (E2-EQs) ranged from 8.24 to $95.28 \mathrm{ng} \mathrm{E} 2 \mathrm{~g}^{-1} \mathrm{dw}$. As a result, the relative estrogenic potencies of three fractions in this study descended in the order of Fraction $3>$ Fraction $2>$ Fraction 1 . The results of the bioassay analysis indicated the heavy pollution status of these sites with estrogenic contaminants. In this study, five selected chemicals, the natural estrogens 17 $\beta$-estradiol (E2) and estrone (E1), and the xeno-estrogens 4-octylphenol (OP), 4-nonylphenol (NP), and Bisphenol A (BPA) were also analyzed using the in vitro bioassay. The estrogenic activity of these chemicals were $\mathrm{E} 2>\mathrm{E} 1>\mathrm{NP}>\mathrm{OP}>\mathrm{BPA}$.
\end{abstract}

(C) 2006 Elsevier Ltd. All rights reserved.

Keywords: Estrogenic activity; Sediments; E2-EQs; Haihe and Dagu Rivers; In vitro bioassay; MCF-7 cell line

\section{Introduction}

Some chemicals released to the environment are able to mimic the behavior of natural endogenous estrogens. And they are suspected of being responsible for an increase in the disruption of the normal physiological functions of the endocrine systems of mammals, fish, birds, reptiles and invertebrates (Golden et al., 1998; Tyler et al., 1998). These chemicals include: natural estrogens, such as $17 \beta$-estradiol and estrone; synthetic estrogens, such as $17 \alpha$-ethinylestradiol; as well as xeno-estrogens, such as alkylphenols (including nonylphenol and octylphenol) and Bisphenol A (Gray and Metcalfe, 1997; Staples et al., 1998;

\footnotetext{
* Corresponding author. Tel.: +8610 62849334; fax: +861062923563.

E-mail address: gbjiang@mail.recees.ac.cn (G. Jiang).
}

Hasselberg et al., 2004; Balch and Metcalfe, 2006). Also some persistent organochlorine pesticides (DDT derivatives, such as $o$, $p^{\prime}$-DDT) have been proved to have estrogenic potency (Gaido et al., 1997; Soto et al., 1995; Bonefeld-Jorgensen et al., 2005; Greenlee et al., 2005). There are many significant classes of chemicals that have been analyzed in detail, as well as Polychlorinated Biphenyls (PCBs) (Vaccaro et al., 2005; Kitamura et al., 2005; Gierthy et al., 1997) and Polybrominated diphenyl ethers (PBDEs) (Verslycke et al., 2005), primarily due to their potential endocrine-disrupting activity. Furthermore, for a number of compounds, the endocrine disrupting potency is unknown; and in environmental matrices, many chemicals are present as complex mixtures with other compounds, which may interact to produce additive, greater than additive, or antagonistic effects (Safe et al., 1997). In vitro cell bioassays based on the 
mechanism of action of estrogens provide a rapid, sensitive and inexpensive solution to some of the limitations of chemical analysis. They can be useful to determine the total biological potency of a mixture of chemicals or environmental extracts as well as individual substances. The estrogenic or anti-estrogenic activity of any chemical is due to the ability of the compound to interact with the estrogen receptor (ER) of the cell. Some in vitro assays that act through the ER mode, such as the E-Screen-assay, the yeast estrogen screen (YES)-assay or receptor binding-assays, have been developed to screen for estrogenic or anti-estrogenic activity of chemicals (Bolger et al., 1998; Gaido et al., 1997; Payne et al., 2000). These biological methods have been previously used to detect the estrogenic activity in complex extracts from environmental samples, such as pulp and paper mill sludge and effluents, and particulate matter in air and sediments (Clemons et al., 1998; Koistinen et al., 1998). In most studies, only a few active agents were identified due to the complex composition of the samples (Koh et al., 2005; Legler et al., 2002).

The Haihe River, the largest water system in northern China, flows through the Tianjin area. The Tianjin region has a long history as an industrial city and has a population of 9.2 million. Industrial and domestic waste waters from the city and agricultural effluent discharge into the Haihe and Dagu Rivers which carries the water to the Bohai Sea at Tanggu influx (Yuan et al., 2004). The aim of this study was to determine the in vitro estrogenic activity in sediments collected from five locations along the Haihe and Dagu Rivers. There are no previous records of the estrogenic potential of contaminants present as complex mixtures in these areas. In this study, the estrogenic effect was assessed with a constructed ER-responsive cell line. In addition, several selected chemicals, namely $17 \beta$-estradiol, estrone, octylphenol, nonylphenol and Bisphenol A, were tested for estrogenic potency in the in vitro bioassay.

\section{Materials and methods}

\subsection{Reagents}

The following standards and reagents were used in this study: $17 \beta$-estradiol (E2, 98\%) and estrone (E1, 99\%) (Sigma, Germany), 4-octylphenol (OP, >98\%) and 4-nonylphenol (NP, >98\%) (Tokyo Kasei Kogyo Co. LTD, Japan), Bisphenol A (BPA, 97\%) (Acros Organics, NJ), silica gel 60, column chromatography (Merck, Germany), anhydrous sodium sulfate $\left(\mathrm{Na}_{2} \mathrm{SO}_{4}\right)$, acid-

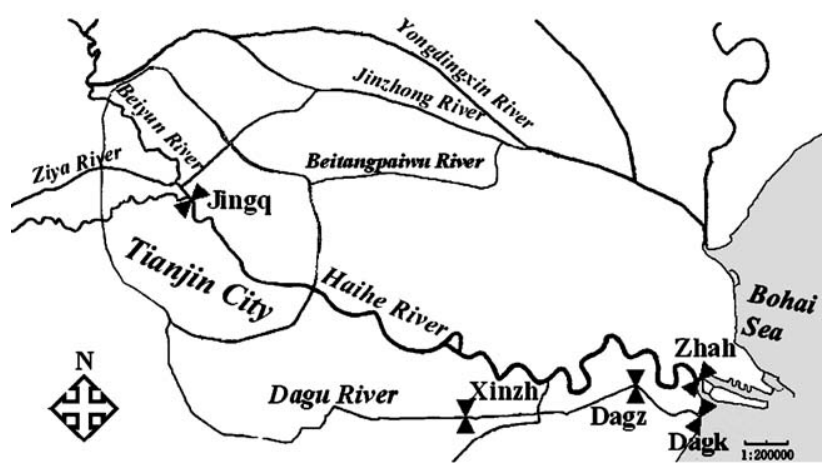

Fig. 1. Sediment sampling locations (marked with $\mathbf{\mathbf { X }}$ ) along the Haihe and Dagu Rivers, China. activated copper powder, 99\% (Fluka), activated florisil, 60-100 mesh size (Sigma, St. Louis, Mo, USA), $n$-hexane (99\%) and methanol (Merk, Germany), and dichloromethane (DCM, 99\%) (TEDIA, USA).

The following were used for cell culturing and testing: Dulbecco's Modified Eagle's Medium (Sigma), the LIVE/DEAD ${ }^{\circledR}$ Viability/Cytotoxicity Kit (L-3224) (Molecular Probes, Invitrogen, Eugene, OR), the luminescence receptor gene assay system (LucLite ${ }^{\mathrm{TM}}$ kit) (Packard BioScience, Netherlands). Milli-Q (MilliQ-185, USA) purified water was used throughout. The bioassay cell culture, previously used to measure estrogenic activity in sediment samples, was the human breast cancer cell line MCF-7 that has been stably transfected with a receptor gene to allow expression of the luciferase enzyme under the control of an estrogen-regulatory element (Khim et al., 1999).

\subsection{Sampling}

Sediment samples were collected from five sites along the Haihe and Dagu Rivers on November 15-16, 2003 (Fig. 1). The Jingangqiao (Jingq) sampling site lies in an urban district and is an important crossing point of several branches of the Haihe River. Site Zhahou (Zhah) is in the estuary of the Haihe River. Dagu River is an important drainage river in Tianjin, and sampling sites Xinzhuangzi (Xinzh), Daguzhong (Dagz) and Dagukou (Dagk) are in the Dagu River

Samples of sediments $(<10 \mathrm{~cm}$ depth) were collected with a stainless steel grab and then placed into hexane-rinsed glass jars with aluminum foil coverings. All sediment samples were immediately transferred to the laboratory and kept at $-20{ }^{\circ} \mathrm{C}$ in the refrigerator. The samples were freeze-dried (FD-1, China), homogenized using a blender with stainless steel blades, and passed through a $63-\mu \mathrm{m}$ sieve before extraction.

\subsection{Sediments extraction and fractionation}

Five $\mathrm{g}$ of the freeze-dried sediment was mixed with $10 \mathrm{~g}$ of silica gel $60,15 \mathrm{~g}$ of $\mathrm{Na}_{2} \mathrm{SO}_{4}$ to remove residual moisture, and $10 \mathrm{~g}$ of copper powder to remove the sulfur. The sediment was then refluxed with a mixture of $300 \mathrm{~mL}$ DCM and hexane (3:1) for $16 \mathrm{~h}$ in a Soxhlet apparatus. After extraction, the solvent-soluble material was back extracted into hexane by rinsing the solvent three times with $15 \mathrm{~mL}$ hexane in a separating funnel. The extract was rotary evaporated $\left(\sim 40^{\circ} \mathrm{C}\right)$ (Buchi, Switzerland) and concentrated to $1 \mathrm{~mL}$.

The concentrated sediment extract was further fractionated into three fractions according to the method described previously (Hilscherova et al., 2000; Khim et al., 1999). Briefly, the extracts were added to a column that contained $10 \mathrm{~g}$ of activated florisil and $100 \mathrm{~mL}$ of hexane was eluted to obtain Fraction 1 that contained the PCBs and a portion of the PCDD/PCDFs. A mixture of hexane containing 20\% DCM was next used to elute organochlorine (OC) compounds, PAHs, alkylphenolethoxylates and the remaining PCDD/PCDFs to obtain Fraction 2. Fraction 3 was eluted with a mixture of DCM containing $20 \%$ methanol and contained the most polar compounds. The MCF-7 bioassay was performed on each fraction to calculate the contribution that each of these fractions made to the overall ER-mediated activity. The fractions were then rotary evaporated $\left(\sim 40^{\circ} \mathrm{C}\right)$ and concentrated to $1 \mathrm{~mL}$.

\subsection{Cell culture conditions and bioassay}

Bioassay of the estrogenic activity of each sample with the MCF-7 cell line was done as previously described (Khim et al., 1999). In brief, 60 interior wells of a 96-well culture plate were each seeded with $250 \mu \mathrm{L}$ cell suspension at a density of about 60,000 cells well $^{-1}$. Cells were cultured overnight under aseptic conditions in a humidified $\mathrm{CO}_{2}$ incubator at $37{ }^{\circ} \mathrm{C}$ and $5 \% \mathrm{CO}_{2}$ prior to dosing. Six dilutions of $\mathrm{E} 2$ were prepared at concentrations of $0.001,0.003,0.01,0.03$, 0.1 and $0.3 \mathrm{nM}$. The dilutions were then added to the wells at three wells per dilution. Extract dilutions were diluted by the same method to give six dilutions and added to wells in the same way. Solvent control was added to three wells. Cells were then incubated for $72 \mathrm{~h}$ in a humidified $\mathrm{CO}_{2}$ incubator at $37^{\circ} \mathrm{C}$ and $5 \%$ $\mathrm{CO}_{2}$ after which the luciferase assay was carried out. Briefly, MCF-7 cells were washed three times with phosphate-buffered saline (PBS) buffer, after removal of culture medium, and then lysed with $75 \mu \mathrm{L}$ PBS buffer containing $\mathrm{Ca}^{2+}$ and $\mathrm{Mg}^{2+}$. Then $75 \mu \mathrm{L}$ luciferase assay reagent was added to each well. Plates were incubated for $20 \mathrm{~min}$ at room temperature in a dark place. Luciferase activities 
were measured with an automate luminometer (Dynatech ML 3000 Luminometer; Chantilly, VA). Extract responses, expressed as mean relative luminescence units (RLUs) of the three replicate wells, were converted to relative response units, expressed as a percentage of the maximum response observed for $\mathrm{E} 2\left(\% \mathrm{E} 2_{\max }\right)$. The toxic equivalent was calculated according to the method described by Villeneuve et al. (2000).

Parallel to the MVLN assay the extract of interest was tested for cytotoxicity towards the MCF-7 cells using a LIVE/DEAD ${ }^{\circledR}$ Viability/Cytotoxicity Kit. Only a dose range without any obvious cytotoxic effect was applied to the bioassay (Hilscherova et al., 2002).

\subsection{Chemical analysis}

In this study, the concentrations of OP, NP and BPA in samples were determined by GC-MS using an Agilent 6890 GC coupled with a 5973 Mass Selective Detector. The analytical methods and GC-MS-SIM conditions were described previously (Jin et al., 2004). The levels and distribution patterns of the selected organochlorine pesticides (OCPs $=p, p^{\prime}$-DDT, $o, p^{\prime}$-DDT, $p, p^{\prime}$-DDE, $p$, $p^{\prime}$-DDD, $\alpha-, \beta-, \gamma-$ and $\left.\delta-\mathrm{HCH}\right)$ in surficial sediments were investigated by means of gas chromatography (HP-1 fused silica capillary column, $50 \mathrm{~m}$ length $\times 0.32 \mathrm{~mm}$ i.d. $\times 0.25 \mu \mathrm{m}$ film thickness) coupled with a micro-electronic capture detector $(\mathrm{GC}-\mu \mathrm{ECD})$. The temperatures of injector and detector were 220 and $300{ }^{\circ} \mathrm{C}$, respectively. Oven temperature increased from $80^{\circ} \mathrm{C}$ (held for $1 \mathrm{~min}$ ) to $180{ }^{\circ} \mathrm{C}$ (held for $2 \mathrm{~min}$ ) at the rate of $50^{\circ} \mathrm{C} / \mathrm{min}$, followed to $230^{\circ} \mathrm{C}$ (held for $2 \mathrm{~min}$ ) at the rate of $5{ }^{\circ} \mathrm{C}$, and then programmed to $270{ }^{\circ} \mathrm{C}$ at $10{ }^{\circ} \mathrm{C} / \mathrm{min}$, held for 15 min (Yang et al., 2004, 2005).

\section{Results and discussion}

\subsection{In vitro bioassay}

The mean \% values of luciferase response/E2 2 max response were used to generate the dose-response curves. The dose-response curve of E2 used as a standard in the MVLN-luc bioassay was sigmoidal in appearance: $y=y_{0}+a /\left[1+\exp \left(x_{0}-x\right) / b\right]$. Luciferase induction was reproducible with coefficients of variation $(\mathrm{CV})$ less than $20 \%$. The limit of detection (LOD) and $\mathrm{EC}_{50}$ for luciferase induction by $\mathrm{E} 2$ were $0.0013 \pm 0.0004$ and $0.0046 \pm 0.0008 \mathrm{nM}$, respectively. Typical results (Total extract and fractions of Xinzh Sample) obtained with the MVLN-luc analysis of sediment extracts and the fractions are given

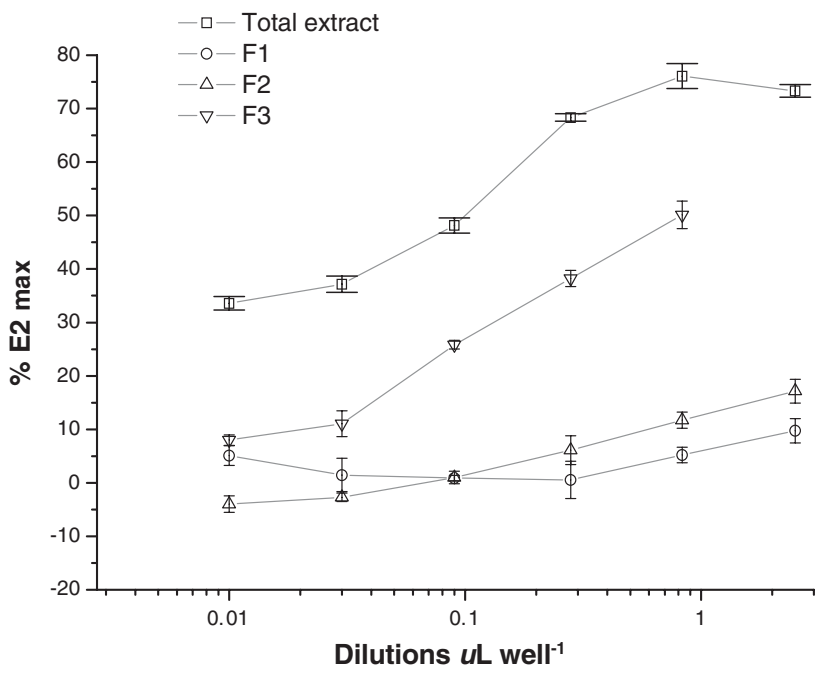

Fig. 2. Typical dose-response curves for the induction of luciferase activity in the MVLN-luc assay by the total sediment extracts and sediment extract fractions, F1, F2 and F3. Luciferase induction is expressed in terms of the percentage of luciferase activity relative to that of $0.3 \mathrm{nM}$ E2 (E2 $\left.2_{\max }\right)$. Values represent the mean \pm S.D.; $n=3$.<smiles>CC1CC2c3ccc(O)cc3CCC2C2CCC(O)C12</smiles>

\section{7ß-estradiol (E2)}<smiles>CC12CCC3c4ccc(O)cc4CCC3C1CCC2=O</smiles>

estrone $(E 1)$<smiles>CC(C)(C)CC(C)(C)c1ccc(O)cc1</smiles>

\section{4-octylphenol (OP)}

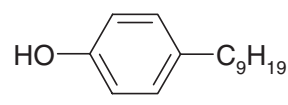

\section{4-nonylphenol (NP)}<smiles>CC(C)(c1ccc(O)cc1)c1ccc(O)cc1</smiles>

Bisphenol A (BPA)

Fig. 3. Structural formulae of the tested natural estrogens and xeno-estrogens.

(Fig. 2). The estrogenic activity in samples derived from bioassay analysis was expressed as E2 equivalent quantity (E2-EQs, ng E2-eq $\mathrm{g}^{-1} \mathrm{dw}$ ), which is based on the standard curve of E2. Significant responses were defined as those greater than three times the standard deviation of the response obtained from the solvent control.

\subsection{Estrogenic activity of selected chemicals}

Five chemicals with known estrogenic activity, namely the natural estrogens $17 \beta-E 2$ and E1, and the xeno-estrogens NP, OP and BPA, were tested in the MVLN-luc assay. Their structural formulae are shown in Fig. 3. The luciferase activity was detected at the six concentrations in the bioassay and their dose-response curves are shown in Fig. 4. The most sensitive estrogenic dose-responses were found with the natural estrogens, E2 and E1. The xeno-estrogens NP and OP produced $50 \%$-E $2_{\text {max }}$ responses at a concentration of about $1 \times 10^{4} \mathrm{nM}$, and BPA was weakly estrogenic at a concentration of about $1 \times 10^{5} \mathrm{nM}$. 


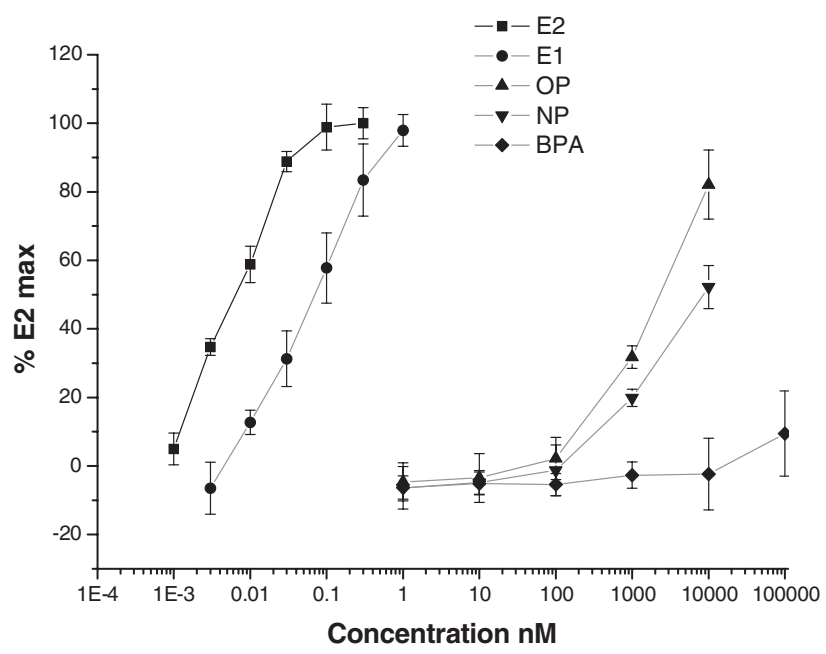

Fig. 4. Response in the in vitro bioassay toward $17 \beta-E 2$, E1, NP, OP and BPA. Luciferase induction is expressed in terms of the percentage of luciferase activity relative to that of $0.3 \mathrm{nM} \mathrm{E} 2\left(\% \mathrm{E} 2_{\max }\right)$. Values represent the mean \pm S.D.; $n=3$.

These three xeno-estrogens at low concentrations showed responses lower than the response of the solvent control. Both NP and OP were cytotoxic to the MCF-7 cells at a concentration of about $1 \times 10^{5} \mathrm{nM}$.

The relative potencies $(\mathrm{E} 2=1)$ were determined as $\mathrm{EC}_{50}$-values from the dose-response curve. The $\mathrm{EC}_{50}$ values and the relative potencies (REP) compared to E2 of the selected chemicals are summarized in Table 1. E1 was about 15 times less potent, NP about $1 \times 10^{5}$ times less potent and OP about $3 \times 10^{5}$ times less potent than E2. The observed relative estrogenic potencies of E2, E1, NP and OP are in agreement with reference data (Gutendrof et al., 2001; Legler et al., 2002; Van den Belt et al., 2004). These chemicals were previously analyzed in another in vitro bioassay using a recombinant yeast cell culture. The reported relative potency of NP in the recombinant yeast culture assays was $7 \times 10^{-3}$ (Routledge and Sumpter, 1996) and $2.5 \times 10^{-5}$ (Rutishshauser et al., 2004), that of E1 was $9 \times 10^{-2}$ (Nick et al., 1997), and that of OP was $7.8 \times 10^{-6}$ (Rutishshauser et al., 2004). An interesting observation is the estrogenic activity of BPA in the yeast culture assay which had a relative potency of $1.1 \times 10^{-4}$ and was the most potent in Rutishshauser et al.'s (2004) study among NP, OP and BPA. In contrast, Gutendrof et al. (2001) reported a relative potency of $2.5 \times 10^{-5}$ in the MVLN-cells assay for BPA, but in this study, BPA showed weak estrogenic activity at a high concentration of $1 \times 10^{5} \mathrm{nM}$. As a result, the relative estrogenic potencies of selected chemicals in this study descended in the order of $2>\mathrm{E} 1>\mathrm{NP}>\mathrm{OP}>\mathrm{BPA}$.

Table 1

Comparison of $\mathrm{EC}_{50}$ and the relative potencies (REP) obtained in this study and in other studies

\begin{tabular}{llllll}
\hline Chemical & \multicolumn{2}{l}{ Values this study } & & \multicolumn{2}{l}{ Published values } \\
\cline { 2 - 3 } \cline { 5 - 6 } & $\mathrm{EC}_{50}, \mathrm{nM}$ & $\mathrm{REP}$ & & $\mathrm{EC}_{50}, \mathrm{nM}$ & $\mathrm{REP}$ \\
\hline $\mathrm{E} 2$ & $4.6 \times 10^{-3}$ & 1 & & $0.015^{\mathrm{a}}$ or $0.005^{\mathrm{b}}$ & 1 \\
$\mathrm{E} 1$ & 0.069 & 0.06 & & $0.078^{\mathrm{a}}$ or $0.48^{\mathrm{b}}$ & $0.2^{\mathrm{a}}$ or $0.01^{\mathrm{b}}$ \\
$\mathrm{OP}$ & 1484 & $3 \times 10^{-6}$ & & $4286^{\mathrm{c}}$ & $1.4 \times 10^{-6 \mathrm{c}}$ \\
$\mathrm{NP}$ & 4619 & $1 \times 10^{-6}$ & & $463^{\mathrm{a}}$ or $400^{\mathrm{b}}$ & $3 \times 10^{-5 \mathrm{a}}$ or $1.25 \times 10^{-5 \mathrm{~b}}$ \\
$\mathrm{BPA}$ & $\mathrm{LE}$ & $\mathrm{LE}$ & & $200^{\mathrm{b}}$ & $2.5 \times 10^{-5 \mathrm{~b}}$ \\
\hline
\end{tabular}

REP of E2 was determined as 1.

LE: BPA did not reach $50 \%$ of max E2 response in bioassay.

${ }^{a}$ Values are from Van den Belt et al. (2004).

${ }^{\mathrm{b}}$ Values are from Gutendrof et al. (2001).

c Values are from Legler et al. (2002).

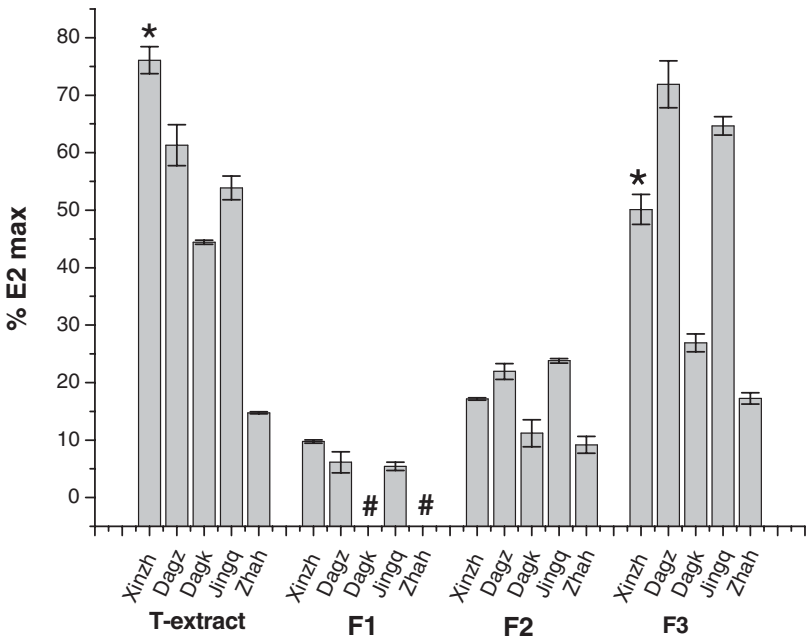

Fig. 5. Maximal luciferase induction in the MCF-7 assay elicited by total extracts and individual fractions separated by florisil column chromatography (F1: Fraction 1, F2: Fraction 2 and F3: Fraction 3). Response magnitude is expressed as percentage of $\mathrm{E} 2_{\max }{ }^{*}$ : The greatest testing dilution is cytotoxic to the MCF-7 cells; \#: The response is lower than the significant response level.

\subsection{Estrogenic activity of sediment samples}

The results of bioassay measurement of estrogenic activity using MVLN cells to the total and fractionated extracts of surface sediments from Haihe and Dagu Rivers are shown in Fig. 5. Significant induction of luciferase activity was observed with total extracts of all sediments. The maximal induction ( $\left.\% \mathrm{E} 2{ }_{\max }\right)$ caused by extracts was between $14.7 \%$ and $76.1 \%$ of the maximal induction elicited by E2. Three samples elicited luciferase activity that exceeded $50 \% \mathrm{E} 2{ }_{\max }$. The highest activity was observed at location Xingzh near which are many chemical factories. Fractionation of sediment extracts showed different estrogenic activities in the bioassay. The polar fraction (F3) from sediment extract demonstrated higher estrogenic potency than midpolar and non-polar fractions (F2 and F1). The mean response was $16.7 \% \mathrm{E} 2_{\max }$ for $\mathrm{F} 2$ and $46.3 \% \mathrm{E} 2_{\max }$ for $\mathrm{F} 3 . \mathrm{F} 1$ showed the lowest response among the three fractions and the responses of Dagk and Zhah were lower than a statistically significant response. Cytotoxicity, determined by the LIVE/DEAD ${ }^{\circledR}$ Viability/Cytotoxicity Kit, was observed at the greatest testing concentration $\left(2.5 \mu \mathrm{L}\right.$ well $\left.{ }^{-1}\right)$ of total extract and F1 of the Xinzh sample. The E2 equivalent values in the total and fractionated extracts of sediment samples are shown in Table 2. Estrogenic activity was observed in all five samples collected from the Haihe and Dagu Rivers. The E2 equivalents ranged from 5.93 to

Table 2

Estrogenic equivalents (E2-EQs, ng E2 $\mathrm{g}^{-1} \mathrm{dw}$ sediments) determined by bioassays in total crude sediment extracts $(T)$, and in extract fractions (F1, F2 and F3)

\begin{tabular}{llllr}
\hline Sediment site & \multicolumn{4}{c}{ Estrogenic equivalents, $\mathrm{ng} \mathrm{E} 2 \mathrm{~g}^{-1} \mathrm{dw}$ sediment } \\
\cline { 2 - 5 } & $T$ & $\mathrm{~F} 1$ & $\mathrm{~F} 2$ & $\mathrm{~F}$ \\
\hline Jingq & 37 & 5.3 & 12.2 & 56.5 \\
Zhah & 8.2 & $\mathrm{LS}$ & 6.4 & 9.3 \\
Xinzh & 95.3 & 6.6 & 9.3 & 32.2 \\
Dagz & 49.3 & 5.9 & 11.3 & 77.7 \\
Dagk & 37 & $\mathrm{NS}$ & 7.1 & 13.7 \\
\hline
\end{tabular}

LS: Response of sample lower than the significant response. 
Table 3

Published values of the concentrations of OP, NP, BPA $\left(\mathrm{ng} \mathrm{L}^{-1}\right)$ in water and concentrations of OCPs ( $\mathrm{ng} \mathrm{g}^{-1} \mathrm{dw}$ ) in sediments collected from sampling sites

\begin{tabular}{lcrccc}
\hline Sediment site & $\mathrm{OP}^{\mathrm{a}}$ & $\mathrm{NP}^{\mathrm{a}}$ & $\mathrm{BPA}^{\mathrm{a}}$ & $\Sigma \mathrm{HCH}^{\mathrm{b}}$ & $\Sigma \mathrm{DDT}^{\mathrm{b}}$ \\
\hline Jingq & 78.4 & 414 & 126 & 19 & 80.2 \\
Zhah & 66.9 & 701 & 107 & 2.67 & 11.9 \\
Xinzh & 81.3 & 1056 & 109 & 34.3 & 83.5 \\
Dagz & 78.6 & 944 & 97 & 102 & 20.6 \\
Dagk & 71.7 & 485 & 102 & 141 & 3.6
\end{tabular}

a Values are from Jin (Jin et al., 2004).

b Values are from Yang (Yang et al., 2005).

$95.28 \mathrm{ng} \mathrm{E} 2 \mathrm{~g}^{-1} \mathrm{dw}$. The results were about 5 to 10 times higher than those reported from an area of the Korean coast (Koh et al., 2005) and from a Czech Republic river (Hilscherova et al., 2002).

The compounds separated to F1, including PCDDs, PCDFs, and PCBs, are known to elicit effects mediated by the aryl hydrocarbon receptor (AhR). It has been reported that some PCBs and their hydroxylated metabolites could act as weak estrogens. Our previous studies indicated that concentrations of total PCBs in the sediments were relatively high, up to about $154 \mathrm{ng} \mathrm{g}^{-1} \mathrm{dw}$ in the Dagk site (Zhang, 2004). In this study, F1 didn't show high estrogenic potency perhaps due to the AhR-mediated anti-estrogenicity of these compounds that has been reported along with complex interactions between ER and AhR signal transduction (Navas and Seger, 1998; Safe, 1995).

Hilscherova et al. (2002) reported that the estrogenic activity was mainly present in F2. This fraction contained PAHs, their derivatives, organochlorine pesticides and alkyl phenols. PAHs were the major chemical group found in this fraction (Wang et al., 2003). Several PAHs, including benzo $[\alpha]$ pyrene $(\mathrm{BaP})$ and benz $[\alpha]$ anthracene $(\mathrm{BaA})$, or their oxygenated derivatives, have been shown to act as estrogenic compounds in ER-regulated receptor gene assays (Chaeles et al., 2000). Recently, several other PAHs, including fluorine, fluoranthene, pyrene, chrysene, phenanthrene and anthracene, were found to act as very weak inducers of ER-mediated activity in MCF-7 cells (Vondráček et al., 2002). Alkyl phenols, such as NP and OP, have been reported to be estrogenic in both in vitro and in vivo experiments, and pesticides, such as $o, p^{\prime}$-DDT, have also been shown to elicit weak estrogenic activity. Relatively high concentrations of OP, NP, BPA and selected organochlorine pesticides were found at the sampling sites (Table 3). In a previous study (Shao et al., 2004) a high level of vitellogenin (VTG), a possible biomarker of estrogen (Sumpter and Jobling, 1995), was detected in all the male sea catfish collected from the Zhah site. Chang et al. (2003) compared the effects of BPA, NP and OP on in vitro VTG synthesis in primary cultures of hepatocytes of Chinese minnow Phoxinus oxycephalus. The results indicated that exposure to $10^{-5} \mathrm{M}$ BPA and $10^{-4} \mathrm{M} \mathrm{NP}$ and OP induced significant in vitro VTG synthesis. But exposure to high concentrations of these three compounds in vivo were required to induce VTG synthesis. Van den Belt et al. (2003) found significant VTG induction in rainbow trout exposed to NP, OP and BPA at concentrations of 100,30 and $1000 \mu \mathrm{g} \mathrm{L}^{-1}$, respectively. Other studies have reported that $1 \mu \mathrm{g} \mathrm{L}^{-1} \mathrm{NP}$ (Schwaiger et al., 2002) and $500 \mu \mathrm{g} \mathrm{L}^{-1} \mathrm{BPA}$ (Lindholst et al., 2000) could induce significant levels of VTG in male rainbow trout. The concentrations of NP, OP and BPA in the water from the Zhah site were much lower than the concentrations that could induce VTG. Our study indicated there has been heavy pollution of this site with other estrogenic contaminants. We also found that concentrations of BPA in sediments of Xinzh and Dagz were 2 to 3 times higher than those in water. Aquatic sediments serve as a kind of enrichment medium for a number of contaminants and thus can act as an integrative measure of exposure of the aquatic ecosystem to these contaminants (Berggrena et al., 1999; Hurst et al., 2004). In our study, the greatest E2 equivalent values were observed in F3 and the results suggest the presence of estrogenic compounds in F3. The estrogenic potency of a number of substances in this group of chemicals in F3 is unknown. For the sites Jingq, Dagz and Zhah, the E2 equivalent values of F3 were higher than the values of the total extracts. Assuming that the contents of the fractions were exactly equal to their content in the total extracts then the results indicate that while F3 contained estrogenic activity, depending on the site, F1 and F2 contained substances that were either antagonistic, synergistic or of no effect on that activity. These results no doubt indicate that some chemicals in the mixture produce estrogenic effects and others can boost or be antagonistic to estrogenic activity, or have no effect.

Some toxic compounds, such as organochlorine pesticides (OCPs), xeno-estrogens (including 4-tert-octylphenol, 4-nonylphenol and bisphenol A), PCBs, PCDDs/PCDFs and mercury, have been reported in the previously studies in this area (Jin et al., 2004; Shi et al., 2005; Wan et al., 2005; Yang et al., 2005; Zhang, 2004). However, few data are available to indicate the level of contamination of estrogenic compounds in these rivers. In vitro MCF-7 bioassay has been shown to be a useful tool for assessing the estrogenic activity of complex environmental mixtures. The estrogenic activities in sediments from the Haihe and Dagu Rivers were significant. However, the application of the bioassay cannot quantify specific compounds. To provide an estimate of the relative level of contamination, it is reasonable to use bioassays combined with instrumental analytical approaches.

\section{Acknowledgement}

This study was supported by a Central Allocation Grant (8730020) awarded by the Research Grants Council, Hong Kong, and the Area of Excellence Scheme under the University Grants Committee of the Hong Kong Special Administration Region, China (Project No. AoE/P-04/2004).

\section{References}

Balch G, Metcalfe C. Developmental effects in Japanese medaka (Oryzias latipes) exposed to nonylphenol ethoxylates and their degradation products. Chemospher 2006;62:1214-23.

Berggrena P, Ishaq R, Zebühr Y, Näf C, Bandh C, Broman D. Patterns and levels of organochlorines (DDTs, PCBs, nonortho PCBs and PCDD/Fs) in male Harbour porpoises (Phocoena phocoena) from the Baltic Sea, the Kattegat-Skagerrak seas and the west coast of Norway. Mar Pollut Bull 1999;38:1070-84.

Bolger R, Wiese TE, Ervin K, Nestich S, Checovich W. Rapid screening of environmental chemicals for estrogen receptor binding capacity. Environ Health Perspect 1998;106:551-7.

Bonefeld-Jorgensen EC, Grünfeld HT, Gjermandsen IM. Effect of pesticides on estrogen receptor transactivation in vitro: a comparison of stable transfected MVLN and transient transfected MCF-7 cells. Mol Cell Endocrin 2005;24:20-30.

Chaeles GD, Bartels MJ, Zacharewski TR, Gollapudi BB, Freshour NL, Carney EW. Activity of benzo[ $\alpha]$ pyrene and its hydroxylated metabolites in estrogen receptor- $\alpha$ receptor gene assay. Toxicol Sci 2000;55:320-6.

Chang BP, Byung HK, Oh SN, Young CC, Young DL, Hae JB, et al. Induction of in vitro vitellogenin synthesis by bisphenol, nonylphenol and octylphenol in Chinese minnow (Phoxinus oxycephalus) hepatocytes. Korean J Biol Sci 2003; 7:227-35.

Clemons JH, Allan LM, Marvin CH, Wu Z, McCarry BE, Bryant DW, et al. Evidence of estrogen- and TCDD-like activities in crude and fractionated extracts of PM10 air particulate material using in vitro gene expression assay. Environ Sci Technol 1998;32:1853-60. 
Gaido KW, Leonard LS, Lovell S, Gould JC, Babai D, Portier CJ, et al Evaluation of chemicals with endocrine modulating activity in a yeast-based steroid hormone receptor gene transcription assay. Toxicol Appl Pharmacol 1997; 143:205-12.

Gierthy JF, Arcaro KF, Floyd M. Assessment of PCB estrogenicity in a human breast cancer cell line. Chemosphere 1997;34:1495-505.

Golden RJ, Noller KL, Titus-Ernstoff L, Kaufman RH, Mittendorf R, Stillman R, et al. Environmental endocrine modulators and human health: an assessment of the biological evidence. Crit Rev Toxicol 1998;2:101-227.

Gray MA, Metcalfe CD. Induction of testis-ova in Japanese medaka (oryzias latipes) exposed to $p$-nonylphenol. Environ Toxicol Chem 1997;16:1082-6.

Greenlee AR, Ellis TM, Berg RL, Mercieca MD. Pregnancy outcomes for mouse preimplantation embryos exposed in vitro to the estrogenic pesticide $o, p^{\prime}$-DDT. Reprod Toxicol 2005;20:229-38.

Gutendrof B, Westendorf J. Comparison of an array of in vitro assays for the assessment of the estrogenic potential of natural and synthetic estrogens phytoestrogens and xenoestrogens. Toxicology 2001;166:79-89.

Hasselberg L, Meier S, Svardal A. Effects of alkylphenols on redox status in first spawning Atlantic cod (Gadus morhua). Aquat Toxicol 2004;69:95-105.

Hilscherova K, Machala M, Kannan K, Blankenship AL, Giesy JP. Cell bioassay for detection of aryl hydrocarbon (AhR) and estrogen receptor (ER) mediated activity in environmental samples. Environ Sci Pollut Res Int 2000;7:159-71.

Hilscherova K, Kannan K, Holoubek I, Giesy JP. Characterization of the estrogenic activity of riverine sediments from the Czech Republic. Arch Environ Contam Toxicol 2002;43:175-85.

Hurst MR, Balaam J, Chan-Man YL, Thain JE, Thomas KV. Determination of dioxin and dioxin-like compounds in sediments from UK estuaries using a bio-analytical approach: chemical-activated luciferase expression (CALUX) assay. Mar Pollut Bull 2004;49:648-58

Jin XL, Jiang GB, Huang GL, Liu JF, Zhou QF. Determination of 4-tertoctylphenol, 4-nonylphenol and bisphenol A in surface waters from the Haihe River in Tianjin by gas chromatography-mass spectrometry with selected ion monitoring. Chemosphere 2004;56:1113-9.

Khim JS, Villeneuve D, Kannan K, Koh CH, Giesy JP. Characterization and distribution of trace contaminants in sediment from Masan Bay, Korea. 2. In vitro gene expression assay. Environ Sci Technol 1999;33:4206-11.

Kitamura S, Jinno N, Suzuki T, Sugihara K, Ohta S, Kuroki H, et al. Thyroid hormone-like and estrogenic activity of hydroxylated PCBs in cell culture. Toxicology 2005;208:377-87.

Koh CH, Khim JS, Villeneuve DL, Kannan K, Johnson BG, Giesy JP. Instrument and bioanalytical measures of dioxin-like and estrogenic compounds and activities associated with sediment from the Korean coast. Ecotoxicol Environ Saf 2005;61:366-79.

Koistinen J, Soimasuo M, Tukia K, Oikari A, Blankenship A, Giesy JP. Induction of EROD activity in Hepa-1 mouse hepatoma cells and estrogenicity in MCF-7 human breast cancer cells by extracts of pulp mill effluents, sludge, and sediments exposed to effluents. Environ Toxicol Chem 1998; 17:1499-507.

Legler J, Dennekamp M, Vethaak AD, Brouwer A, Koeman JH, Van der Burg B, et al. Detection of estrogenic activity in sediment-associated compounds using in vitro reporter gene assays. Sci Total Environ 2002;293:69-83.

Lindholst C, Pedersen KL, Pedersen SN. Estrogenic response of bisphenol A in rainbow trout (Oncorhynchus mykiss). Aquat Toxicol 2000;48:87-94.

Navas JM, Seger H. Antiestrogenic activity of anthropogenic and natural chemicals. Environ Sci Pollut Res Int 1998;5:75-82.

Nick GC, Mehul D, Susila S, Donald PM, Caroline C, Maurice JS. Evaluation of a recombinant yeast cell estrogen screening assay. Environ Health Perpect 1997; 105:734-42.

Payne J, Rajapakse N, Wilkins M, Kortenkamp A. Prediction and assessment of the effects of mixture of four xenoestrogens. Environ Health Perpect 2000;108:983-7.

Routledge EJ, Sumpter JP. Estrogenic activity of surfactants and some of their degradation products assessed using a recombinant yeast screen. Environ Toxicol Chem 1996;15:241-8.

Rutishshauser BV, Pesonen M, Escher BI, Ackermann GE, Aerni HR, Suter MJF, et al. Comparative analysis of estrogenic activity in sewage treatment plant effluents involving three in vitro assays and chemical analysis of steroids. Environ Toxicol Chem 2004;23:857-64.

Safe S. Environmental and dietary estrogens and human health: is there a problem? Environ Health Perspect 1995;103:346-51.

Safe S, Connor K, Ramamoorthy K, Maness S. Human exposure to endocrineactive chemicals: hazard assessment problems. Regul Toxicol Pharmacol 1997;26:52-8.

Schwaiger J, Mallow U, Ferling H, Knoerr S, Braunbeck TH, Kalbfus W, et al. How estrogenic is nonylphenol? A transgenerational study using rainbow trout (Oncorhynchus mykiss) as a test organism. Aquat Toxicol 2002;59:177-89.

Shao J, Shi G, Liu J, Jiang G. A rapid two-step chromatographic method for the quantitative determination of vitellogenin in fish plasma. Anal Bioanal Chem 2004;378:615-20.

Shi JB, Liang LN, Jiang GB, Jin XL. The speciation and bioavailability of mercury in sediments of Haihe River, China. Environ Int 2005;31:357-65.

Soto AM, Sonnenschein C, Chung KL, Fernandez MF, Olea N, Serrano FO. The E-screen assay as a tool to identify estrogens: an update on estrogenic environment pollutants. Environ Health Perspect 1995;103:113-22.

Sumpter JP, Jobling S. Vitellogenesis as a biomarker for estrogenic contamination of the aquatic environment. Environ Health Perspect 1995; 103:173-8

Staples CA, weeks J, Hall J, Naylor C. Evaluation of aquatic toxicity and bioaccumulation of $\mathrm{C}_{8}$ - and $\mathrm{C}_{9}$-alkylphenol ethoxylates. Environ Toxicol Chem 1998; 17:2470-80.

Tyler CR, Jobling S, Sumpter JP. Endocrine disruption in wildlife: a critical review of the evidence. Crit Rev Toxicol 1998;28:319-61.

Vaccaro E, Meucci V, Intorre L, Soldani G, Bello DD, Longo V, et al. Effects of $17 \beta$-estradiol, 4-nonylphenol and PCB 126 on the estrogenic activity and phase 1 and 2 biotransformation enzymes in male sea bass (Dicentrarchus labrax). Aquat Toxicol 2005;75:293-305.

Van den Belt K, Verheyen R, Witters H. Comparison of vitellogenin response in zebrafish and rainbow trout following exposure to environmental estrogens. Ecotoxicol Environ Saf 2003;56:271-81.

Van den Belt K, Berckmans P, Vangenechten C, Verheyen R, Witters H. Comparative study on the in vitro/in vivo estrogenic potencies of $17 \beta$ estradiol, estrone, $17 \alpha$-ethynylestradiol and nonyphenol. Aquat Toxicol 2004:66:183-95

Verslycke TA, Vethaak AD, Arijs K, Janssen CR. Flame retardants, surfactants and organotins in sediment and mysid shrimp of the Scheldt estuary (The Netherlands). Environ Pollut 2005;136:19-31.

Villeneuve DL, Blankenship AL, Giesy JP. Derivation and application of relative potency estimates based on in vitro bioassay results. Environ Toxicol Chem 2000;19:2835-43.

Vondráček J, Kozubík A, Machala M. Modulation of estrogen receptordependent reporter construct activation and $\mathrm{G}_{0} / \mathrm{G}_{1}-S$-phase transition by polycyclic aromatic hydrocarbons in human breast carcinoma MCF-7 cells. Toxicol Sci 2002;70:193-201.

Wan Y, Hu JY, Yang $\mathrm{M}$, An LH, An W, Jin XH, Hattori T, Itoh M. Characterization of trophic transfer for polychlorinated dibenzo- $p$-dioxins, dibenzofurans, non- and mono-ortho polychlorinated biphenyls in the marine food web of Bohai Bay, North China. Environ Sci Technol 2005;39:2417-25.

Wang XJ, Zheng Y, Liu RM, Li BG, Cao J, Tao S. Kriging and PAH pollution assessment in the topsoil of Tianjin area. Bull Environ Contam Toxicol 2003;71:189-95

Yang RQ, Yao ZW, Jiang GB, Zhou QF, Liu JY. HCH and DDT residues in molluscs from Chinese Bohai coastal sites. Mar Pollut Bull 2004;48:795-805.

Yang RQ, Lv AH, Shi JB, Jiang GB. The levels and distribution of organochlorine pesticides (OCPs) in sediments from the Haihe River, China. Chemosphere 2005;61:347-54

Yuan C, Jiang G, Liang L, Xin X, Shi J. Sequential extraction of some heavy metals in Haihe River sediments, People's Republic of China. Bull Environ Contam Toxicol 2004;73:59-66.

Zhang, Q.H. Study on characteristics of dioxin-like compounds in Taihu Lake and Haihe River Basin in Tianjin. Ph.D. thesis, the Chinese Academy of Sciences, Beijing, China, 2004; 87-104. 